\title{
MIOCENE WILKINSONIA FRUITS (HICKSBEACHIINAE, PROTEACEAE) FROM THE BASE OF THE YALLOURN FORMATION, LATROBE VALLEY, VICTORIA
}

\author{
by Andrew C. Rozefelds
}

(with two tables, one text-figure and one plate)

Rozeffi..Js, A.C., 1995 (30:vi): Miocene Wilkinsonia fruits (Hicksbeachiinae, Proteaceae) from the base of the Yallourn Formation, Latrobe Valley, Victoria. Pap. Proc. R. Soc. Tasm. 129: 59-62. https://doi.org/10.26749/rstpp.129.59 ISSN 0080-4703.

Tasmanian Herbarium, GPO Box 252C, Hobart, Tasmania, Australia 7001.

Wilkinsonia bilaminata F. Muell., 1879 is recorded from interseam clays at the base of the Yallourn Formation, Latrobe Valley, Victoria. The genus was widely distributed throughout eastern Australia during the Oligo-Miocene. The palynological record for both Yallourn and the type locality has not suggested that either Athertonia, the most closely related extant taxon, or the subtribe Hicksbcachiinae were present in these localities. There are two inferences from these results; the suggested affinities of some of the pollen taxa may be in error, or the pollen of the Wilkinsonia plant may be under-represented in these sites and has been overlooked.

Key Words: Proteaceae, Hicksbeachiinae, Athertonia, Wilkinsonia, fossil fruit, Victoria, Australia, Tertiary, biostratigraphy.

\section{INTRODUCTION}

Wilkinsonia bilaminata was described by Mueller (1879, 1883) on the basis of woody fruits from deep leads, below basalts in the Orange and Gulgong gold-mining areas of New South Wales. Since then similar fruits have been collected from Glencoe, in Central Queensland, and the status of the genus has been re-examined following comparisons with the extant genera Athertonia and Heliciopsis in the subtribe Hicksbeachiinae (Rozefelds 1990a, 1992). Wilkinsonia was shown to be more closely related to the modern genus Athertonia, a rainforest endemic restricted to northeastern Queensland (Rozefelds 1992).

Fossil fruits referable to Wilkinsonia have been recently collected from the interseam clays at the base of the Yallourn Formation. Palynological studies of interseam clays at the base of the Yallourn Formation indicate a late early to middle Miocene age based on the presence of Triporopollenites bellus Zone and the first appearance of Proteacidites symphyonemoides (Sluiter 1984). Partridge (pers. comm.) in Macphail et al. (1994) gives an absolute date of 17.0 myrs BP for the base of the Yallourn Coal Seam. The interseam clays are approximately equivalent in age, based upon pollen, to the type locality for Wilkinsonia bilaminata at Gulgong (McMinn 1981). Potassium-argon dates of $14.8 \pm 1.2$ and $13.8 \pm 1.1$ myrs BP for basalts in the Gulgong area that overlie deep leads in this area (Dulhunty 1971) indicate a minimum mid-Miocene age for this flora.

The seed/fruit flora and other plant fragments occur in medium to fine-grained clastics of fluvial or lacustrine origin (Blackburn \& Sluiter 1994). The associated seed/ fruit flora from these interseam clays is diverse but remains unstudied. The seed/fruit flora from the base of the Yallourn Formation includes taxa with affinities to Elaeocarpus (Elaeocarpaceae), Vitaceae, Menispermaceae and Glochidion? (Euphorbaceae).

In this paper, Wilkinsonia bilaminata is recorded from the Miocene clays in the Latrobe Valley. The new material provides additional information on the morphology of the endocarps not evident from the neotype. The biogeographical significance of this new Wilkinsonia record is discussed. The biostratigraphic range of this taxon is also discussed, along with the potential for developing seed/

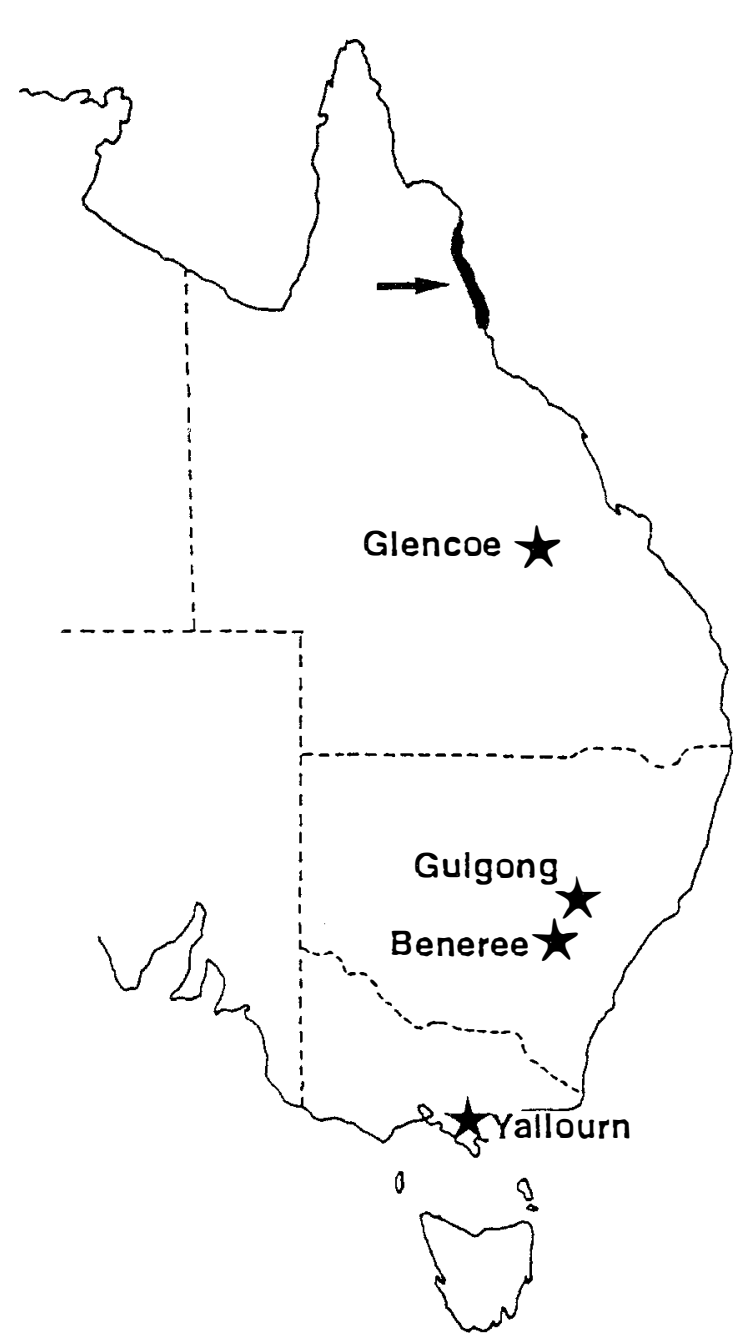

FIG. 1 - Localities mentioned in text and distribution (arrowed) of modern Athertonia in Australia.

fruit-based biostratigraphies. Yallourn fossils described in this paper have been deposited in the Museum of Victoria. 


\section{SYSTEMATIC PALAEOBOTANY}

\section{Family PROTEACEAE \\ Tribe MACADAMIEAE \\ Subtribe HICKSBEACHIINAE \\ Wilkinsonia F. Muell., 1879}

Type species: Wilkinsonia bilaminata F. Muell., 1879.

Vilkinsonia bilaminata F. Muell., 1879.

1879 Wilkinsonia bilaminata F. Muell., p. 170, pl. 3, fig. $4 a, b$.

1883 Wilkinsonia bilaminata F. Muell., p.7, pl. 3.

1992 Wilkinsonia bilaminata F. Muell., emend. Rozefelds, p. 196.

Material examined

NMVP199574-NMVP199578, Base of Yallourn Formation, interseam clays from between the Yallourn and Morwell coal seams, collected from near the top of the Morwell Open Cut Coal Mine, Latrobe Valley, Vicroria. Triporopollenites bellus Zone (pl. 1A-H).

Description of Yallourn material

The endocarps from Yallourn are large, irregularly round to oval in outline, with reticulate lacunose omamentation. The size of the endocarp varies from $38.5-42 \mathrm{~mm}$ long and 36.7-41 mm wide (table 1). Endocarps appear slightly compressed but are elliptical in lateral view. A prominent incipient lateral ridge extends from the apex to the base on either side of the endocarp (pl. 1A-H). A relatively broad lateral field occurs between the incipient ridge and the edge of the endocarp, with minor accessory lateral ridges and irregular rows of small depressions $(\mathrm{pl} .1 \mathrm{~A}-\mathrm{H})$. The width of this region may be different on one side of the endocarp from that on the other within the one specimen (table 1). This lateral field in the Yallourn material extends beyond the rest of the endocarp, forming a slight notch (pl. $1 \mathrm{~A}-\mathrm{H})$. Multiple irregular rows of depressions and poorly defined ridges occur between the lateral ridge and the edge of the endocarp. The endocarp wall, which is $2-3 \mathrm{~mm}$ in thickness, consists of tangentially oriented interweaving fibres. The bases of additional, weakly lignified fibres occur in the lacunae. These fibres extend outwards into what was the fleshy mesocarp of the fruit. Fragments of endocarp examined with the SEM failed to provide additional data on the microstructure in these endocarps.
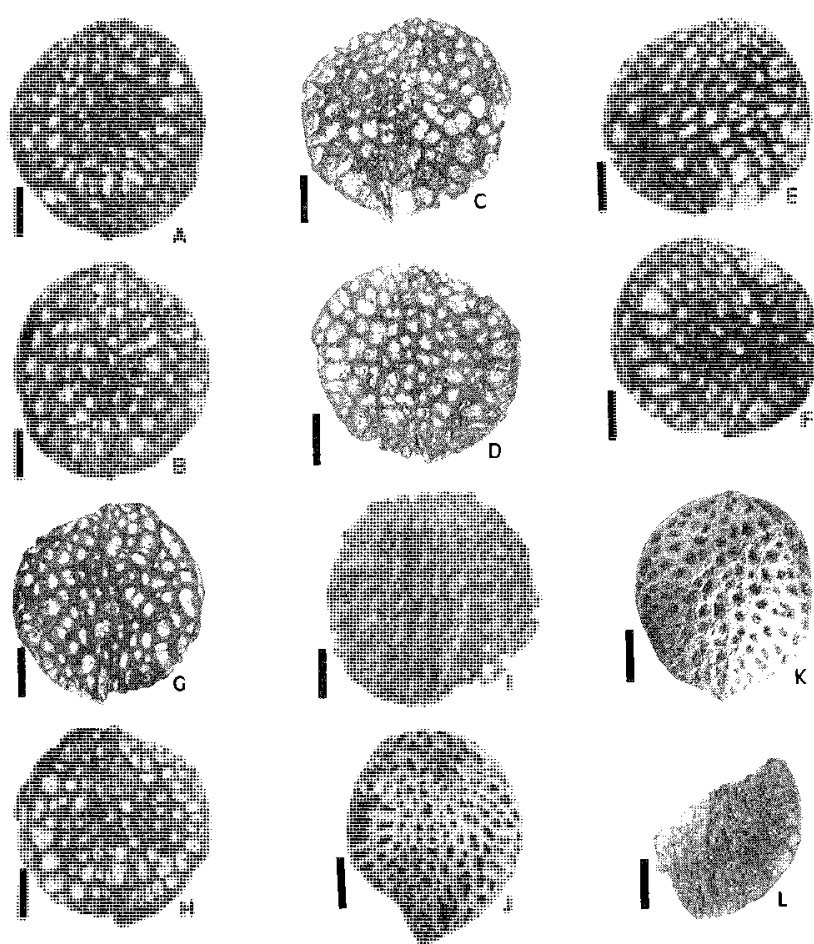

PLATE 1

Wilkinsonia and Athertonia endocarps. $(A-H, L)$ Wilkinsonia bilaminata $F$. Muell. from the interseam clays at the base of the Yallourn Formation.

(A, B) NMVP199577. (C, D) NMVP199574. (E, F) NMVP. 199576. (G, H) NMVP-199575. (1) Neotype of Wilkinsonia bilaminata (NMVP-53092) from the Black Lead, approx. 43-52 $m$ below basalt, Gulgong, New South Wales. (J,K) Extant endocarps of Athertonia diversifolia (C.T. White) L. Johnson and B. Briggs. (L) Fragment of W. bilaminata (NMVP 199578) from Yallourn. Scale bars $=10 \mathrm{~mm}$.

\section{Remarks}

The features that allow referral of these fossil endocarps to Wilkinsonia are the lacunose ornamentation and the continuous lateral ridge that extends from the apex to the base of the endocarp. The new material from Yallourn is closely comparable to the neotype (NMVP53902) of W. bilaminata from the Gulgong locality. Additional material of W. bilaminata, figured or mentioned by Mueller (1879, 1883) from Beneree in New South Wales, has not been located.

TABLE 1

Measurements of Yallourn W. bilaminata F. Muell.

\begin{tabular}{lcccc}
\hline $\begin{array}{l}\text { Registration Number } \\
\text { (NMV) }\end{array}$ & $\begin{array}{c}\text { Length } \\
(\mathrm{mm})\end{array}$ & $\begin{array}{c}\text { Width } \\
(\mathrm{mm})\end{array}$ & $\begin{array}{c}\text { Maximum width of lateral fields }(\mathrm{mm}) \\
\text { one side }\end{array}$ & $\begin{array}{c}\text { other side } \\
\text { P199574 }\end{array}$ \\
\hline P199575 & 38.6 & 40 & 10.7 & 9.7 \\
P199576 & 38.5 & 36.7 & 9.0 & 10.5 \\
P199577 & 39.2 & 41 & 10.8 & 8.0 \\
\hline
\end{tabular}


Two species of Wilkinsonia are recognised (Rozefelds 1992). Both taxa share multiple irregular rows of small depressions, with accessory ridges occurring between the incipient ridge and the edge of the endocarp. The two species differ in the width of the lateral field between the incipient ridge and the edge of the endocarp. In $W$. bilaminata this zone is broad, while in W. glencoensis it is relatively narrow (Rozefelds 1992). The additional material from Yallourn shows variation in the width of this region. The new material from Yallourn also provides additional differences between these taxa. The base of the endocarp in W. bilaminata is slightly notched, and the lateral field extends further than the main region of the endocarp (pl. 1A-H). The notch is absent from $W$. glencoensis. The neotype of W. bilaminata from Gulgong was also strongly flattened, as well as damaged, due to pyritic deterioration in storage; this made comparison with $W$. glencoensis difficult. The new material of $W$. bilaminata does not show the weakly defined longitudinal ridges seen in the neotype. These longitudinal ridges were initially considered to be due, in part, to compression (Rozefelds 1992). This interpretation is supported by the new material from Yallourn, as the lacunose ornamentation of the endocarps is irregular and does not form ridges. The weakly defined longitudinal ridges in the neotype are considered to be preservational artifacts.

The Proteaceae pollen taxa described from both the Home Rule site and the interseam clay between the Yallourn and Morwell Coal Measures are recorded (table 2). The Proteaceae pollen taxon shared between these sites is Proteacidites symphyonemoides, which has been considered by Martin (1978) to have affinities with Symphionema (subfamily Proteoideae). The other Proteaceae pollen taxa known from either the Yallourn Formation or Home Rule locality are not considered to have affinities with Athertonia or Hicksbeachiinae. There is no evidence for linking any of the known pollen taxa and endocarps to the same parent plant (table 2).

The fossil distribution of Wilkinsonia demonstrates that proteaceous plants with endocarps closely comparable to extant Athertonia were widespread in eastern Australia during the Oligo-Miocene (fig. 1). Athertonia, the extant taxon most closely related to W. bilaminata, occurs in the tropical rainforest communities of northeastern Queensland (Rozefelds 1992). The discovery of W. bilaminata at the base of the Yallourn seam, and Elaeocarpus and Menispermaceae endocarps, Vitaceae seeds, and possibly Glochidion fruits (Rozefelds $1990 \mathrm{~b}$, pers. obs.) indicates that forests with affinities to tropical-warm temperate closed forests occurred in the Yallourn area during the midMiocene.

Discussion

While considerable advances have occurred in palynological studies of the Latrobe Valley Coal Measures (Luly et al. 1980, Sluiter \& Kershaw 1982, Macphail et al. 1994), the megaflora and local plant communities that gave rise to these units remain poorly known (Blackburn \& Sluiter 1994). The new megafloral material allows recognition of the subtribe Hicksbeachiinae in these units, something not suggested by the existing pollen studies. This failure to identify plants with affinities to Athertonia and the Hicksbeachiinae in the pollen flora could be due to either the pollen of these trees being under represented in the palynofloras or, alternatively, to the proposed generic affinities of some Proteaceae pollen being in error. Some support for the earlier proposition comes from Kershaw (1973) and Walker \& Flenley (1979), who considered the Proteaceae to be equally or under-represented in fossil units, and this is consistent with the low mobility of Proteaceae pollen (Kershaw \& Strickland 1990). Kershaw (1973) and Walker \& Flenley (1979) also considered that the source of Proteaceae pollen was from locally growing trees. The possibility of locally growing source trees for pollen is consistent with the unabraded condition of the fruits. It is somewhat surprising, therefore, that pollen of these trees has nor been identified in the palynofloras. Hence, it is considered equally likely that the supposed generic affinities of at least one of these pollen types may be in error.

The palynomorph Propylipollis reticuloscabratus (Harris) was considered by Dettmann \& Jarzen (1991) to be closely comparable to pollen of Hicksbeachia/Gevuina. Specht et al. (1992) recorded the stratigraphic range of Hicksbeachial Gevuina pollen type from the Campanian through to the Pliocene in southeastern Australia. This pollen type was considered morphologically distinctive by Dettmann \& Jarzen (1991). Johnson \& Briggs (1975), however, placed these extant genera in two separate subtribes, i.e. Hicksbeachia (subtribe Hicksbeachiinae) and Gevuina (subtribe Gevuininae). The significance of this pollen type

TABLE 2

Proteaceae pollen taxa recorded

\begin{tabular}{lll}
\hline $\begin{array}{l}\text { Home Rule Deposit, } \\
\text { Gulgong* }\end{array}$ & $\begin{array}{c}\text { Core LY1279, } \\
\text { Latrobe Coal Measures } \dagger\end{array}$ & Suggested affinity $\ddagger$ \\
\hline $\begin{array}{l}\text { Proteacidites ivanhoensis } \\
\text { P. symphyonemoides }\end{array}$ & - & Orites, Helicia, Macadamia \\
& P. symphyonemoides & Symphionema \\
& P. tuberculatus \\
& P. obscurus & \\
& P.sp cf. callosus & Agastachys type \\
Beauprea & \\
BanksialDryandra & Beauprea \\
& Banksia, Dryandra \\
\hline
\end{tabular}

\footnotetext{
* From the Triporopollenites bellus Zone at Gulgong (McMinn 1981).

† From the base of the Yallourn Formation (Sluiter 1984).

$\ddagger$ Martin (1978) and Macphail et al. (1994).
} 
in relation to the existing tribes recognised by Johnson $\&$ Briggs (1975) is unclear and requires further study.

The new record of Wilkinsonia, unpublished results for Elaeocarpus (Elaeocarpaceae) (Rozefelds 1990b) and Rhytidocaryon wilkinsonii (Menispermaceae) (Rozefelds, pers. obs.), and their relationship to existing palynological biostratigraphic zones demonstrate the potential for developing seed/fruit biostratigraphic-based systems for the Tertiary of southeastern Australia. There is a relative paucity of records of pollen/spores and megafossil material in organic connection in the Australian Tertiary (Christophel 1984, Rozefelds et al. 1992). The development of fruit/seed taxa, or leaf and dispersed cuticle zones, in conjunction with palynological studies would provide the opportunity to test the biostratigraphic framework proposed by either palynologists or megafossil workers. The association of different organ taxa in the same geological units would also allow the parent plant and plant communities to be more accurately reconstructed. Systematic data from a number of organ taxa of the same parent plant would also permit more rigorous comparisons with the extant flora and better phylogenetic conclusions to be drawn.

\section{ACKNOWLEDGEMENTS}

This material was collected during field work organised by DrA. Drinnan (School of Botany, University of Melbourne). I am grateful for comments and advice by Drs Mary Dettmann, A. Douglas and G. Kantvilas on this manuscript. Access to Museum of Victoria collections was provided by Elizabeth Thompson. Bob Gaulton provided assistance and allowed access to the Morwell and Yaliourn Coal Seams in the Latrobe Valley.

\section{REFERENCES}

Bl.Ackburn, D.T. \& Slutrer, I.R.K., 1994: The Oligo-Miocene coal floras of south eastern Australia. In Hill, R.S. (Ed.): HISTORY OF THE AUSTRALIAN VEGETATION: CRETACEOUS TO RECENT. Cambridge University Press, Cambridge: 328-367.

Christor'Hel, D.C., 1984: Early Tertiary Proteaceae: The first floral evidence for the Musgraveinae. Aust. J. Bot.32:177186.

DEITManN, M.E. \& JaRYHN, D.M., 1991: Polien evidence for Late Cretaceous differentiation of Proteaceac in southern polar forests. Can. J. Bot. 69: 901-906.

Dulfunly, J.A., 1971: Potassium-argon dates and their significance in the liford-Mudgee-Gulgong region. J. Proc. R. Soc. N. S. W.104: 39-44.

Jominon, L. A. S. \& Briggis B.G., 1975: On the Proteaceae the evolution and classification of a southern family. Bot. J. Linn. Soc. Lond. 70: 83-182.
Kershaw, A.P., 1973: Late Quaternary vegetation of the Atherton Tableland, north-easc Queensland, Australia, Unpubl. PhD thesis, Aust. Nat. Univ. [not seen].

Kfrshaw, A.P. \& Strickl.and, K.M., 1990: A 10 year pollen trapping record from rainforest in northeastern Queensland, Australia. Rev. Palaeobot. Palynol. 64: 281288.

Luty, J., Siumer, I.R.K. \& Krrshaw, A.P., 1980: Pollen studies of Tertiary brown coals: preliminary analyses of lithocypes within the Latrobe Valley, Victoria. Monash Publ. Geogr. 23: $1-78$

Macphan, M.K., Ailfy, N.F., Trusweli, E.M. \& Siutter, I.R.K., 1994: Early Tertiary vegecation: evidence from spores and pollen. In Hill R.S. (Ed.): HISTORY OF THE AUSTRALIAN VEGETATION: CRETACEOUS TO RECENT. Cambridge University Press, Cambridge: 189261.

MARIN, H.A., 1978: Evolution of the Australian flora and vegecation chrough the Terriary, evidence from pollen. Alcheringa 2: 181-202.

McMinN, A, 1981: A Miocene microflora from the Home Rule Kaolin Deposit. Q. Notes Geol. Surv. NSW 43: 1-4.

Mufl..FR, F. VON, 1879: Appendix D. Descriptive notes on the Tertiary flora of New South Walcs, Annual Report, 1878 Mines Department, New South Wales:169-172.

MUeLLiR, F. VON, 1883: Observations on new vegetable fruits of the auriferous drifts Dec. 2. GEOLOGICAL SURVEY OF VICTORIA, John Ferres, Government Printer, Melbourne: $23 \mathrm{pp}$.

Rozkfeids, A.C., 1990a: A mid Tertiary rainforest flora from Capella, central Queensland. In Douglas, J. G. \& Christophel, D. C. (Eds): PROCEEDINGS, THIRD INTERNATIONAL ORGANIZATION OF PALAEOBOTANY 1988. A-Z Publishers, Melbourne: 123-136.

Rozkenios, A.C., 1990b: A taxonomic study of extant and fossil fruits of the genus Elacocarpus (Elaeocarpaceae) in Australia and New Zealand. Unpubl. Hons thesis, Bot. Dep., Univ. Adetaide.

Rozbrios, A.C., 1992: The suberibe Hicksbeachiinae (Proteaceae) in the Australian Tertiary. Mem. Qld Mus. 32: $1.95-202$

Roybeitss, A. C., Christophet, D. C. \& Alley, N. 1992 Tertiaty occurrence of the fern Lygodium (Schizaeaceae) in Australia and New Zealand. Mem. Qld Mus. 32: 203222

Si.UTT:R, I.R.K., 1984: Palynology of Oligo-Miocene Brown coal seams, Latrobe Valley. Unpubl. PhD thesis, Monash Univ.

SIUTHR, I.R. \& KERSHAW, A.P., 1982: The nacure of the lace Tertiary vegetation in Australia, Alcheringa 6: 211-222.

SPFCHT, R.L., DE'TIMANN, M.E. \& JARZHN, D.M., 1992: Community associations and structure in the Late Cretaccous vegetation of south eastern Australasia and Antarctica. Palaeogeogr., Palaeoclimatol., Palaeoecol. 94 : 283-309.

WAIKtiR, D. \& FlENUlYY, J.R., 1979: Late Quaternary vegetational history of the Enga P'rovince of upland Papua and New Guinea. Phil. Trans. R. Soc. Lond. B 286: 265-344.

(accepted 26 April 1995) 